\title{
KEBIJAKAN NEGARA TERHADAP HUBUNGAN KONTRAKTUAL SEBAGAI HAK ASASI MANUSIA DI INDONESIA
}

(State Policy of Contractual Relationship As a Human Rights in Indonesia)

\author{
Zulfirman \\ Fakultas Hukum Universitas Islam Sumatera Utara \\ Jalan Timor Ujung No. 5 Kelurahan Gaharu, Kecamatan Medan Timur, Medan \\ Email: zulfirman13@yahoo.com
}

Naskah diterima: 17 Mei 2013; revisi: 3 Juni 2013; disetujui: 25 November 2013

\begin{abstract}
Abstrak
Pasal 11 Kovenan Internasional Hak Sipil dan Hak Politik mewajibkan negara untuk menghormati, melindungi dan menegakkan hubungan kontraktual sebagai hak asasi manusia di Indonesia. Bagaimana kebijakan negara melindungi, menghormati dan menegakan hubungan kontraktual sebagai hak asasi manusia di Indonesia. Penelitian ini menggunakan data sekunder terdiri dari bahan hukum primer, bahan hukum sekunder dan bahan hukum tertier. Data diperoleh melalui studi kepustakaan. Penelitian melalui pendekatan filosifis yuridis normatif. Data dianalisis secara kualitatif dengan metode penafsiran untuk menemukan nilai dasar atas hubungan kontraktual sebagai hak sipil bagian dari hak asasi manusia di Indonesia yang dijadikan dasar dalam penegakan hukum. Hubungan kontraktual sebagai hak sipil sudah diatur dalam Kitab Undang Undang Hukum Perdata sebelum diratifikasinya kovenan Internasional hak sipil dan hak politik. Negara Indonesia tidak konsekuen melaksanakan kovenan internasional hak sipil dan hak politik dengan memberi sanksi pidana kepada pelaku yang tidak memenuhi kewajiban kontraktualnya. Perlu dilakukan reposisi peran dan fungsi negara untuk perlindungan hak sipil sebagai kebijakan politik dalam pembentukan hukum dan penegakan hukum di masa datang.
\end{abstract}

Kata kunci: negara, kontrak, hak asasi manusia

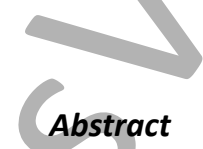

Article 11 of the International Covenant on Civil and Political Rights requires states to respect, protect and enforce contractual relations as human rights in Indonesia. How state policy to protect, respect and uphold the contractual relationship as human rights in Indonesia. This study uses secondary data consists of primary legal materials, secondary and tertiary legal materials. The data obtained through the study of literature. Research through juridical normative and philosophical approach. Data were analyzed qualitatively by using interpretative method to find the value of the basic civil rights of a contractual relationship as part of human rights in Indonesia were used as a basis for law enforcement. Contractual relationship as a civil rights set out in the draft of Civil Code before the ratification of the International Covenant on civil and political rights. Indonesian state does not consistently implement the international covenant of civil rights and political rights proved to sanction the perpetrators who did not fulfill its contractual obligations. Necessary to reposition the role and function of the state for the protection of civil rights as a political policy formation and law enforcement in the future. Keywords : state, contract, human rights 


\section{A. Pendahuluan}

Reformasi konstitusi sebagaimana terlihat dalam amandeman Pasal 1 ayat $(2)^{1}$ dan ayat $(3)^{2}$ Undang-Undang Dasar Negara Republik Indonesia Tahun 1945 di Indonesia, secara eksplisit, hukum diartikan sebagai undangundang. Jadi, di luar undang-undang tidak ada hukum; oleh karenanya hukum tidak tertulis yang hidup di tengah-tengah masyarakat (living law) diartikan sebagai sumber hukum materiil.

Secara akademis, dampak amandemen Pasal 1 ayat (2) dan ayat (3) UUD 1945, negara Indonesia menganut aliran legisme atau positivisme hukum, artinya semua aktivitas individu, masyarakat, berbangsa dan bernegara harus diatur dalam suatu peraturan formal yakni undang-undang. ${ }^{3}$ Konsekuensi dianutnya aliran legisme ini hukum dan politik mempunyai hubungan secara timbal balik. Pengaruh politik terhadap hukum sangat terasa dalam pembentukan dan pemberlakukan hukum, karena undang-undang adalah produk legislatif sebagai representasi politik; sedangkan pengaruh hukum terhadap politik terlihat pada legalitas menjalankan politik atau kekuasaan.
Salah satu, keterkaitan antara hukum dengan politik akibat dianutnya pemikiran legisme (positivisme hukum) dapat dilihat dari kemauan politik untuk melindungi hak asasi manusia (HAM) di Indonesia yang semula merupakan hak moral diimplementasikan ke dalam undangundang yang secara eksplisit dituangkan dalam Bab XA UUD 1945, dan peraturan perundangundang lainnya. ${ }^{4}$

Secara internasional, ada tiga instrumen pokok tentang HAM, salah satunya adalah The Internastional Covenant on Civil and Political Rights (ICCPR). ${ }^{5}$ Dalam kovenan ini, esensi hak sipil ialah hak kebebasan fundamental yang diperoleh sebagai hakikat dari keberadaan seorang manusia, sedangkan esensi hak politik ialah hak dasar dan bersifat mutlak yang melekat di dalam setiap warga negara yang harus dijunjung tinggi dan di hormati oleh negara dalam keadaan apapun. ${ }^{6}$ Oleh karena itu, HAM yang termuat di dalam ICCPR bersifat hak negatif atau disebut juga obligation of conduct, ${ }^{7}$ artinya negara tidak bertindak dalam rangka merealisasikan hak-hak yang diakui dalam kovenan tersebut; menikmati hak sipil, politik 
tidak memerlukan peranan negara. ${ }^{8} \mathrm{Jadi}$, negara berfungsi sebagai alat bantu (penolong) yang terakhir dalam mempertahankan aturan itu. ${ }^{9}$ Untuk itu, perlu ditentukan peranan dan posisi negara yang tepat dalam upaya melindungi, menegakkan dan menghormati hak sipil dan hak politik di Indonesia pasca pengesahan ICCPR.

$I C C P R$ berkomitmen untuk menghormati hak-hak sipil dan politik individu antara lain: hak untuk hak untuk hidup, kebebasan individu, kebebasan berbicara, kebebasan berkumpul, hak memilih dan hak atas proses hukum dan peradilan yang adil. Salah satu wujud hak sipil dapat dilihat dari kebebasan membuat kontrak atau perjanjian ${ }^{10}$ sebagaimana ditetapkan pada Pasal 11 ICCPR melarang penggunaan penjara sebagai hukuman atas tidak dipenuhinya kewajiban kontraktual. Dari ketentuan ini nyata sekali peran negara bersifat pasif terhadap individu untuk menikmati hak-hak sipilnya. Namun, dalam praktek tidak jarang hubungan kontraktual sebagai hak sipil diselesaikan melalui domain hukum Pidana. Misalnya masalah penitipan sebagai hu-bungan sipil (keperdataan) diselesaikan melalui Pasal $372 \mathrm{KUH}$ Pidana demikian juga Pasal 378 KUH Pidana tentang penipuan, bahkan tidak jarang perjanjian melakukan pekerjaan antara individu dengan pemerintah dalam penyediaan barang dan jasa yang diduga menimbulkan kerugian bagi negara diselesaikan melalui tindak pidana korupsi. Hal yang sama juga terjadi atas perbuatan yang menyerang nama baik seseorang diselesaikan melalui domain hukum pidana.

Bertitik tolak, haksipil merupakan haknegatif di mana negara berperan sebagai penolong terakhir atas pelanggaran hak tersebut, untuk itu perlu dilakukan kajian tentang kebijakan negara untuk menegakan dan menghormati hak sipil setelah terjadinya reformasi konstitusi dan pengesahan ICCPR di Indonesia khususnya tentang politik hukum terhadap hak sipil dalam hubungan kontraktual sebagai HAM.

\section{B. Permasalahan}

Berdasarkan latar belakang tersebut di atas, maka masalah dalam penelitian ini adalah bagaimana kebijakan negara Indonesia dalam upaya menegakkan dan menghormati hak sipil khususnya hubungan kontraktual sebagai HAM setelah terjadinya reformasi konstitusi dan disahkannya ICCPR di Indonesia. Atau dengan kalimat lain, bagaimana posisi negara dalam dalam upaya melindungi hubungan kontraktual sebagai hak sipil yang merupakan bagian HAM di Indonesia.

\section{Metode Penelitian}

Penelitian ini menggunakan data sekunder, yang terdiri dari bahan hukum primer, yaitu UUD 1945, Undang-Undang Nomor 39 Tahun 1999

8 Ifdal Kasim, "Memajukan Advokasi Terhadap Hak-Hak Ekonomi, Sosial dan Budaya, dalam Ifdal Kasim, Johanes dan Masenus Arus, Hak Ekonomi, Sosial, Budaya, Esai-esai Pilihan (Jakarta: Elsam, 2001), hlm. xiii. Bambang Waluyo, Viktimologi Perlindungan Saksi dan Korban (Jakarta: Sinar Grafika, 2011), hlm. 8.

$9 \quad$ N.E Algra, et al., Mula Hukum Beberapa Bab mengenai hukum dan ilmu untuk pendidikan hukum dalam Pengantar Ilmu Hukum, terjemahan J.C.T. Simorangkir (Jakarta: Binacipata 1983), hlm. 67.

10 Pasal 1338 KUHPerdata yang menentukan persetujuan yang dibuat secara sah mengikat bagi para pihak sebagaimana undang-undang. Ketentuan ini memberi pengertian hubungan kontraktual adalah mutlak hak individu. 
tentang HAM, Undang-Undang Nomor 12 Tahun 2005 tentang Ratifikasi Kovenan Internasional Hak Sipil dan Hak Politik ${ }^{11}$, dan Kitab Undang Undang Hukum Perdata (KUHPerdata) serta undang-undang lain yang relevan. Bahan hukum skunder berupa pendukung bahan hukum primer berupa Rancangan Undang-Undang (RUU), pendapat para ahli. Bahan hukum tertier terdiri dari kamus hukum, ensikopedia hukum maupun politik.

Data diperoleh melalui studi kepustakaan dengan cara mengumpulkan data berupa literatur tentang HAM dan politik baik berupa undang-undang, buku literatur, jurnal hukum, makalah, artikel atau pendapat para ahli yang relevan dengan penelitian ini baik yang ada di media elektronik maupun media cetak.

Data dianalisis secara kualitatif melalui pendekatan filosofis normatif yuridis tentang hak sipil tentang hubungan kontraktual sebagai HAM di Indonesia. Analisis data dilakukan dengan cara berfikir kritis filosifis (rasionalisme kritis) terhadap norma-norma hukum tentang hak sipil sebagai HAM guna menemukan prinsip atau nilai dasar yang dijadikan acuan kebijakan hukum mengatur dan menegakkan hak sipil khususnya hubungan kontraktual sebagai HAM oleh negara Indonesia. Metode yang digunakan adalah metode penafsiran, yakni penafsiran autentik, historis, gramatikal dan teleologis terhadap ketentuan hukum hak sipil sebagai HAM. Kebenaran yang akan dikemukakan dalam penulisan ini adalah kebenaran berdasarkan rasional yang melibatkan aksioma dan teori.

\section{Pembahasan}

\section{Kandungan nilai filsafat hukum dalam Pembukaan UUD 1945}

Dalam kontek kenegaraan, pembahasan tentang kedaulatan menjadi hal yang dominan, karena berkenaan dengan kekuasaan yang tertinggi dalam negara. Doktrin tentang kedaulatan dalam negara dapat dijelaskan salah satunya melalui teori kontrak sosial. ${ }^{12}$ Dalam dunia politik, kontrak sosial ini menjadi penting diperhatikan, karena ada hubungannya dengan ide-ide penting dari politik seperti kehendak rakyat, legitimasi dan kewajiban politik.

Bagi bangsa Indonesia, kontrak sosial merupakan fakta sejarah yang nyata terjadi, bukan suatu asumsi akademis, sebagaimana terlihat dari embrional kelahiran negara Indonesia $^{13}$ diawali Kongres Pemuda ${ }^{14}$ tahun 1928 yang melahirkan Sumpah Pemuda pada tanggal 28 Oktober 1928 yang isinya bertanah air satu, berbangsa satu, dan berbahasa satu

11 Untuk selanjutnya disingkat UUPKIHSHP.

12 Jean Jacques Rousseau, Kontrak Sosial, terjemahan, Sumardjo, (Jakarta: Erlangga, 1986), hlm. vii, Kontrak sosial merupakan karya cipta bersama dari pergaulan politik, membentuk serta membatasi praktek politik dengan menyediakan sarana yang kita pergunakan, dan dengan sadar atau tidak ia mampu merumuskan permasalahan sosial dan dapat memahami apa yang sedang kita kerjakan.

13 Goerge Ms T. Kahin mengatakan: dengan telah dicetuskannya ikrar-ikrar nasionalisme pertama pada saat itu, penentuan bendera dan lagu kebangsaan, serta keputusan agar bahasa Melayu dijadikan bahasa Indonesia yaitu bahasa nasional dari negara yang akan dilahirkan, sebagian besar golongan berpendidikan modern mengikat diri kepada perjuangan baru yang memukau yang bernama Indonesia. Herbert Feith dan Lance Castles, Pemikiran Politik Indonesia 19451965, terjemahan, Yubhar (Jakarta: LP3ES, 1995), hlm. xxxix.

14. Kongres ini diadakan oleh perkumpulan-perkumpulan pemuda Indonesia yang berdasarkan kebangsaan dengan namanya: Jong Java, Jong Soematera, Pemuda Indonesia, Seka Rukun, Jong Islamieten Bond, Jong Batak Bond, Jong Celebes, Pemuda Kaum Betawi dan Perhimpunan Pelajar-pelajar Indonesia. Mohd. Koesnoe, Catatan-catatan Terhadap Hukum Adat Dewasa ini (Surabaya: Arilangga University Press, 1979), hlm. 134. 
yaitu Indonesia. Sumpah Pemuda tersebut merupakan semangat persatuan ${ }^{15}$ yang mewujudkan perjuangan bangsa Indonesia melawan penjajahan oleh bangsa lain (Belanda) yang dilandasi oleh motif ekonomi ${ }^{16}$ yang melahirkan kegiatan politik. ${ }^{17}$ Sumpah pemuda ini dapat diartikan sebagai serangan langsung terhadap sendi-sendi masyarakat kolonial yang berdasarkan garis warna dan status sosial yang pincang. ${ }^{18}$ Sumpah pemuda itu pulalah yang menumbuhkembangkan pergerakan nasional Indonesia melawan penjajahan, yang puncaknya Indonesia memproklamirkan kemerdekaannya tanggal 17 Agustus 1945.

Pernyataan kemerdekaan Indonesia yang ditindaklanjuti dengan pembentukan UUD 1945 sebagai tindak lanjut sumpah pemuda, ${ }^{19}$ dari pandangan politik, merupakan kemauan politik bersama bangsa Indonesia sebagai wujud kontrak sosial yang tujuannya untuk memperlihatkan, bahwa pemerintah harus dilihat seolah-olah didirikan oleh rakyat dan dievaluasi apakah bertujuan memberikan perlindungan di mana peme-rintah memang dibentuk untuk itu. ${ }^{20}$

Tindak lanjut Sumpah Pemuda sebagai kontrak sosial melahirkan kemerdekaan bangsa Indonesia memberi penjelasan sumber kedaulatan negara Indonesia. Kedaulatan ${ }^{21}$ meliputi dua hal yang acap kali membingungkan serta tidak mudah dipisahkan dalam praktek, namun berbeda menurut logika: (1) kekuasaan atau kelompok kekuasaan apakah yang sebenarnya paling tinggi dalam suatu masyarakat, dan apakah suatu supremasi itu mutlak hal ini merupakan isu politik; (2)

15 Semangat persatuan telah terasa sejak awal persidangan kongres Pemuda ketika dalam akhir pidato pembukaan Ketua Sidang Soegondo menyerukan "perangilah pengaruh cerai berai dan majulah terus ke arah Indonesia bersatu yang kita cintai." S. Silalahi, Dasar-dasar Indonesia Merdeka versi Para Pendiri Negara (Jakarta: Gramedia, 2001), hlm. 19.

16 Soekarno dalam pidato Presiden pada hari ulang tahun kemerdekaan tanggal 17 Agustus 1952, mengatakan: "Revolusi Indonesia pun adalah bentroknya dua puak tenaga yang menghantam satu sama lain. Pihak kita waktu itu adalah satu puak tenaga, pihak Belanda waktu itu pun adalah satu puak tenaga. Pihak kita adalah ibarat satu pabrik, pihak Belanda adalah ibarat satu pabrik. Dua pabrik ini mencoba mengalahkan satu sama lain. Pihak Indonesia versus Belanda, pabrik kemerdekaan versus pabrik penjajahan (Herbert Feith dan Lance Castles, Op.Cit., hlm. 55).

17 Pertentangan antara kepentingan Pemerintah Kolonial di satu pihak dan kepentingan rakyat jajahan di lain pihak pada waktu itu dirumuskan dengan kata-kata :"Kaum sana memperkuat kedudukan untuk mengangkut rezeki sebanyak-banyaknya dari Indonesia ke negeri asalnya yaitu negeri Belanda, sedangkan kaum sini berketetapan hati untuk menentukan nasib sendiri dan menggunakan kekayaan tanah air bagi kepentingan bangsa Indonesia sendiri". Pertentangan ini dinamakan oleh pelajar dan mahasiswa Indonesia sebagai antithese kolonial. (S. Silalahi, Loc.cit,).

18 PT, Cipta Adi Pustaka, Ensiklopedi Nasional Indonesia Buku 15 (Jakarta: PT.Cipta Adi Pustaka, 1991), hlm. 399.

19 Sebagian kalangan menyebutkan kontrak sosial terjadi pada sidang BPUPKI yang didirikan pada tanggal 28 Mei 1945. Djon Pakan, Kembali ke Jati diri Bangsa Indonesia (Jakarta: Millennium Publisher, 2002), hlm.127-130. Kontrak sosial hanya merupakan konstruksi juridis sebagai dasar untuk menerangkan bagaimana negara itu terjadi, bagaimana negara itu ada, bagaimana adanya kekuasaaan dalam negara itu, dan ada pada siapa kekuasaan itu, serta bagaimana sifatnya. Soehino, Ilmu Negara (Yogjakarta: Liberty, 1980), hlm 127. Kontrak sosial sebagai teori dasar lahirnya suatu negara terdapat dua pendapat yang berbeda, satu pihak mengatakan kontrak sosial itu memang benar-benar terjadi sebagai suatu kenyataan sejarah seperti yang dikemukakan oleh Ibnu Khaldun, Thomas Hobbes, John Locke, Montesquieu, Rousseau, berbeda dengan Imanuel Kant yang menyatakan kontrak sosial atau perjanjian kemasyarakat bukanlah suatu peristiwa sejarah. J.J. von Schmid, Ali-ahli Pikir Besar Tentang Negara Dan Hukum, terjemahan (Jakarta: Pembangunan, 1965), hlm 243-244.

20 Barbara Goodwin, "social contract" dalam Adam Kupper dan Jessica Kuper, Ensiklopedi Ilmu-Ilmu Sosial, Edisi Kedua, (Jakarta: Raja-Grapindo Persada, 2000), hlm. 973.

21 Jean Jacques Rousseau. Op.cit, hlm. xix. 
pemeliharaan atas keuntungan serta kerugian setiap masyarakat merupakan suatu kekuasaan yang paling penghabisan untuk memutus kata akhir dalam perselisihan antara individu dan kelompok, hal ini merupakan isu hukum. Pernyataan ini ada keterkaitan yang erat antara politik dan hukum demikian pula sebaliknya.

Hubungan antara politik di satu pihak dan hukum pada pihak lainnya, dalam konteks kenegaraan, pada hakekatnya membicarakan hubungan antara kekuasaan dengan hukum. Pernyataan ini pada dasarnya adalah berkenaan dengan dunia meta dari negara atau apa yang seharusnya (das saint). Hal ini senada dengan apa yang ditulis Hannah Arendt, dikutip Michael Freeden, pemerintah dan politik didasarkan pada opini, bukan kebenaran faktual. ${ }^{22}$

Beranjak dari fungsi opini bagi pemerintah dan politik maka yang perlu diperhatikan adalah opini pemerintah dan politik tentang nilai yang dijadikan dasar pembentukan dan penyelenggaran negara Indonesia merdeka. Opini tentang nilai itulah yang nantinya dijadikan acuan untuk menentukan kebijakan negara dalam kegiatan politik, hukum dan ekonomi. Apakah nilai tersebut memihak kepada kepentingan individu, kepentingan publik atau kepentingan masyarakat. Tegasnya, apakah negara Indonesia menganut menganut faham liberal, sosialis atau gabungan keduanya atau menempuh jalan tengah di antara keduanya. Oleh karena itu, fungsi nilai menjadi amat penting dalam pembentukan dan kebijakan politik terhadap hukum atau undang-undang; karena, nilai merupakan opini dalam dunia abstrak yang menjadi acuan norma hukum formal yang biasanya terwujudkan sebagai suatu asas; apakah itu asas hukum atau politik dan ekonomi. Pada sisilain, hukum dalam pengertian nilai pada hakekatnya selalu berkembang berorientasi ke depan dalam rangka menjaga, melindungi dan mempertahankan harkat dan martabat manusia. ${ }^{23}$

Opini tentang nilai bagi bangsa Indonesia dapat dilihat dari alinea ke empat Pembukaan UUD 1945 yang berisikan tentang negara, visi $^{24}$ dan misi ${ }^{25}$ bangsa Indo-nesia, pada frase

"berdasarkan kemerdekaan, perdamaian abadi dan keadilan sosial". Ketiga nilai tersebut berhubungan erat dengan peran dan fungsi negara baik secara internal maupun eksternal. Dari frase ini dapat diketahui opini tentang nilai yang dianut oleh bangsa Indonesia adalah nilai kemerdekaan sebagai ekspresi kebebasan, nilai

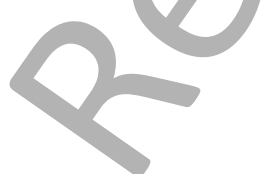

22 Michael Freeden, "Idiologi, Teori Politik, dan Filsafat Politik" dalam Gerald F.Gaus dan Chandran Kukathas, Handbook Teori Politik, terjemahan Derta Sri Widowatie (Bandung: Nusa Media, 2012), hlm. 7.

23 www.suaramerdeka.com/v2/index-php/read/news.smg/2012/05/19/118844/Prof-Sri-Redjeki-sampaikan Orasi-ilmiah-di-Undip (diakses 4 Mai 2013).

24 Pembukaan UUD 1945 dalam kalimat "Disusunlah Kemerdekaan Indonesia itu dalam suatu Undang Undang Dasar Negara Indonesia, yang terbentuk dalam suatu susunan Negara Republik Indonesia yang berkedaulatan Rakyat dengan berdasarkan kepada Ketuhanan Yang Maha Esa, Kemanusiaan yang adil dan beradab, Persatuan Indonesia, dan Kerakyatan yang dipimpin oleh hikmat kebijaksanaan dalam permusyawaratan/ perwakilan, serta dengan mewujudkan suatu Keadilan Sosial bagi seluruh rakyat Indonesia".

25 Pembukaan UUD 1945 pada kalimat "Kemudian dari pada itu, untuk membentuk suatu Pemerintahan Negara Indonesia yang melindungi segenap bangsa Indonesia dan seluruh tumpah darah Indonesia dan untuk memajukan kesejahteraan umum, mencerdaskan kehidupan bangsa, dan ikut serta melaksanakan ketertiban dunia yang berdasarkan kemerdekaan, perdamaian abadi dan keadilan sosial". Hal ini juga menentukan peran dan fungsi negara Indonesia secara internal dan eksternal. 
persamaan sebagai ekspresi keadilan, dan nilai persaudaraan sebagai ekpresi perdamaian. ${ }^{26}$ Tiga prinsip nilai ini berfungsi sebagai nilai pembentukan dan operasionalisasi hukum di Indonesia. Pada sisi lain, dituangkannya ketiga prinsip nilai ini dalam Pembukaan UUD 1945 memberi arti bangsa Indonesia melapiskan nilai kebebasan di atas nilai persamaan yang diikat oleh nilai persaudaraan. ${ }^{27}$

Ada beberapa bukti konkrit dalam undang-undang tentang terjadinya pelapisan nilai kebebasan dengan nilai persamaan, sebagaimana ditentukannya secara eksplisit HAM di dalam BAB XA Amandemen UUD 1945; Pasal 69 ayat (2) Undang-Undang Nomor 39 Tahun 1999 tentang Hak Asasi Manusia (UU HAM), yang mengatakan "setiap hak asasi manusia seseorang menimbulkan kewajiban dasar..."; Pasal 36 UU HAM mengatakan "Hak milik mempunyai fungsi sosial"; Pasal 6 Undangundang Nomor 5 Tahun 1960 tentang Ketentuan Pokok Agraria yang mengatakan "Hak milik berfungsi sosial." 28 Pada sisi lain, terjadi juga pelapisan nilai religius dengan nilai sekuler sebagaimana terlihat pada Pasal 2 ayat (1) Undang-Undang Nomor 1 Tahun 1974 tentang Perkawinan yang mengatakan perkawinan sah berdasarkan agama dan kepercayaannya itu.

Oleh karena, Pembukaan UUD 1945 ini mengandung opini tentang nilai yang dianut oleh bangsa Indonesia, maka tidak dapat dihindari Pembukaan UUD 1945 secara keseluruhan merupakan hard core di bidang politik, hukum, dan ekonomi bagi negara di Indonesia. Artinya Pembukaan UUD 1945 mengandung nilai politik, hukum dan ekonomi yang harus dikonkritkan dalam bentuk norma hukum untuk mengatur ke-hidupan indivudu, bernegara dan bermasyarakat. Dari optik hukum, secara spesifik, Pembukaan UUD 1945 sebagai hard core yang didalamnya berisikan cita hukum (Rechtsidee) yang mengandung nilai-nilai filsafat hukum. ${ }^{29}$ Oleh karena itu, Pembukaan UUD 1945 harus dipegang teguh dalam dunia politik, hukum dan ekonomi yang tidak boleh diubah, sebab mengubah Pembukaan UUD 1945 sama artinya mengubah bentuk negara Indonesia. ${ }^{30}$

26 Tiga prinsip nilai yang ditentukan dalam Pembukaan UUD 1945 tersebut identik dengan slogan revolusi Prancis yaitu liberté, egalité, dan fraternité. Hal yang membedakannya adalah dari aspek penyebab lahirnya slogan tersebut. Bagi bangsa Indonesia kelahiran ketiga prinsip tersebut sebagai reaksi atas tindakan penjajahan yang dilakukan oleh bangsa lain; bagi bangsa Prancis adalah sebagai reaksi terhadap tindakan kesewenang-wenangan dari kaum bangsawan dan rohaniawan dari dalam bangsa Prancis sendiri yang melahirkan revolusi.

27 Secara filosofi juga dapat dilihat terjadinya pelapisan nilai kemerdekaan dengan nilai persamaan sebagaimana terlihat dari Sila Kemanusiaan yang adil dan beradab (nilai kebebasan) dilapiskan dengan Sila Persatuan Indonesia (nilai persamaan).

28 Mohd. Koesnoe, Op.cit., hlm. 159 menulis: ketentuan pasal ini hanyalah tepat bila dihubungkan dengan pengertian hak milik sebagai terjemahan dari pada pengertian "eigendom" di dalam BW. Kurang tepat bila pengertian hak milik didasarkan pada ketentuan Pasal 33 ayat (3) UUD 1945 maupun pengertian hak milik menurut hukum adat. Pendapat demikian ini dapat dimaklumi karena hak milik dalam arti eigendom adalah hak milik mutlak sebagai wujud nilai kebebasan yang dimiliki oleh setiap individu menurut alam fikiran Barat yang individualis.

29 Mohd. Koesnoe, "Mengamati Konsep Hukum di Dalam Masyarakat Kita", Varia Peradilan, 105 (1994): 110.

30 Kesepakatan MPR pada saat akan melakukan amandeman UUD 1945 pada tahun 1999 menetapkan pembukaan UUD 1945 tidak dapat diubah. Secara historis ketatanegaraan Indonesia, terbukti merubah pembukaan UUD merubah negara Indonesia; Pembukaan UUD RIS merubah visi, misi negara Indonesia menjadi bentuk republik federasi; Pembukaan UUDS 1950 merubah visi dan misi serta bentuk negara menjadi republik kesatuan. Perhatikan amanat Presiden Soekarno pada Ulang Tahun Proklamasi Kemerdekaan Indonesia, 17 Agustus 1959: 
Pelapisan nilai kebebasan di atas nilai persamaan yang termuat di dalam Pembukaan UUD 1945 berpengaruh terhadap kebijakan politik pemerintah dalam menentukan peranan dan fungsinya sebagai pembentuk hukum. Hal ini menjadi persoalan yang krusial dalam tataran operasionalnya bila dikaitkan dengan peranan dankeku-asaan negara Indonesia. Apabila negara dipahami yang memiliki peran dan kekuasaan yang demikian kuat di atas individu, berpeluang besar menindas atau melanggar HAM dari warga negaranya. Sebaliknya apabila peran dan kekuatan kekuasaan negara dipahamkan sebagai penguatan hak-hak individu dari warga negaranya secara seluas-luasnya menyebabkan negara menjadi lemah dan fungsi melindungi menjadi kehilangan makna dan kegunaannya.

Persoalan krusial tentang peran dan fungsi pemerintah merupakan masalah yang dihadapi oleh perpolitikan pada abad ke-20 sebagaimana ditulis Fukuyama, perpolitikan di abad ke-20 sangat dibentuk oleh berbagai kontroversi ukuran dan kekuasaan negara yang pas. Salah satu kebingungan dalam pemahaman tentang kenegaraan adalah, bahwa kata kekuatan sering kali dipakai begitu saja untuk mengacu kepada apa yang disebut lingkup serta pada kekuatan atau kemampuan. ${ }^{31}$ Oleh karena itu, masuk akal untuk membedakan antara lingkup aktivitas negara, yang mengacu pada berbagai fungsi dan tujuan yang berbeda dijalankan Pemerintah, dan kekuatan kekuasaan negara, atau kemampuan negara merencanakan dan menjalankan berbagai kebijakan dan memberlakukan undang-undang secara bersih dan transparan, apa yang sekarang ini umumnya diacu sebagai kemampuan negara atau kemampuan institusional. ${ }^{32}$

Tulisan Fukuyama itu bila dikaitkan dengan penghormatan, penegakan, dan perlindungan hak sipil sebagai HAM; maka negara Indonesia dalam merespon pengaturan hukum tentang HAM harus mampu menempatkan diri dalam dua sisi pilihan, yakni sebagai legulator of rights atau sebagai guardian of human rights. Apabila negara memposisikan dirinya sebagai legulator of rights, maka negara berkewajiban untuk mengimplementasikan nilai kebebasan, nilai

"Kita mencari kesadaran yang sedalam-dalamnya bahwa sifat hakekat Revolusi kita ini tidak bisa lain, tidak bisa lain, daripada dasar dan tujuan yang kita proklamasikan pada tanggal 17 Agustus 1945 !" (Sukarno, Di bawah Bendera Revolusi, (Jakarta: Panitya Penerbit Di bawah Bendera Revolusi, 1964), hlm., 360. Lihat juga www. bphn.go.id /index.php?action=public.id=2008042815080192 (diakses 27 April 2013), kesimpulan konvensi dan rekomendasi Konvensi Hukum Nasional tentang UUD 1945 sebagai landasan Konstitusional Grand Design sistem dan Praktek Hukum Nasional huruf A.1.(a) diselenggarakan pada tanggal 15 - 16 Maret 2006 oleh BPHN di Jakarta.

31 Francis Fukuyama, Memperkuat Negara Tata Pemerintahan dan Tata Dunia Abad 21, terjemahan, A.Zain Rofiqi (Jakarta: Gramedia Pustaka Utama, 2005), hlm. 3. Bandingkan dengan Chirstipher W.Morris, "Negara Modern", dalam Gerald F.Gaus dan Chandran Kukathas, Handbook Teori Politik, terjemahan Derta Sri Widowatie (Bandung: Nusa Media, 2012), hlm 560. Para teoritikus meletakkan kekuasaan koersif negara di tengah-tengah perhatian tetapi hal ini lebih jelas atau lebih mudah dipahami daripada klaim-klaim mereka tentang otoritas. Bahkan, yang membingungkan perihal kekuasaan koersif negara bukanlah justifikasinya untuk mengklaim monopolisasi pemaksaan yang absah. Otoritas yang diklaim negara, terutama, kedaulatan, memang luas biasa. Dalam hal tertentu, negara lebih mudah sekaligus lebih sulit untuk dijustifikasi. Penggunaan pemaksaan oleh negara sebenarnya lebih sederhana daripada yang biasa diasumsikan. Tidak sulit menjustifikasi penggunaan pemaksaaan terhadap para pembunuh dan pelaku penyiksaan. Yang sulit dijustifikasi ialah kekuasaan normatif penuh yang diklaim oleh negara.

32 Francis Fukuyama, Op.Cit., hlm. 8. 
persamaan dan nilai persaudaraan dituangkan dalam norma hukum yang mengatur tentang hak sipil sebagai HAM. Dalam hal ini, negara berperan menjadikan hak moral sebagai hak hukum. Pada posisi ini, negara sebagai pemberi hak kepada indivudu hal ini berdampak negara di atas individu, sehingga kebebasan individu dapat dikurangi demi kepentingan negara. Pemikiran ini senada dengan Jeremy Bentham dan Edmund Burke yang menulis hak asasi sebagai tidak mendasar. Hak itu timbul dari tindakan pemerintah, atau berkembang dari tradisi. Argumentasi Bentham untuk itu adalah "bagi saya, hak merupakan anak hukum; dari hukum riil lahir hak riil, tetapi dari hukum imajiner, dari hukum alam, lahir hak imajiner.... Hak alamiah adalah omong kosong belaka, hak yang kodrati dan tidak bisa dicabut adalah omong kosong retorik-omong kosong yang dijunjung tinggi-tinggi".33 Pernyataan Bentham ini jelas menganut paham legisme absolut. Dalam hal ini, nilai yang ditonjolkan negara adalah nilai persamaan dan persaudaraan, artinya negara dalam membuat norma hukum dengan memahamkan HAM sebagai hak positif. Dari situ, norma hukum yang dibuat lebih menonjolkan kewajiban dari pada hak. ${ }^{34}$
Secara praktis, aplikasi nilai persamaan sebagaimana disebutkan di atas, dapat dilihat dalam lintasan sejarah perpolitikan ketatanegaran di Indonesia yang melahirkan negara otoriter. Pada masa orde baru yang lebih menekankan pembangunan ekonomi di mana hukum dijadikan sarana untuk merekayasa sosial (tool of social enginering) se-bagaimana dikemukakan oleh Roscou Pound ${ }^{35}$ yang diadopsi dan dimodifikasi oleh Mochtar Kusumaatmadja yang melahirkan teori hukum pembangunan di Indonesia yang mengutamakan stabilitas.

Pemikiranhukumsebagairekayasasosialyang dikemukan Pound sesungguhnya merupakan penghalusan hukum dari pemikiran Karl Marx dalam bukunya yang berjudul Doe Deitsche Ideologie (Ideologi Jerman) mengemukakan ekonomi mempengaruhi suprastruktur hukum dan politik yang dipergunakan sebagai alat ekonomi untuk mensejahterakan masyarakat manusia. ${ }^{36}$ Pada sisi lain, pemikiran hukum sebagai rekayasa masyarakat adalah bertujuan untuk mendamaikan pemikiran tentang hukum antara tuntutan-tuntutan yang saling bertentangan antara kebutuhan akan stabilitas dan kebutuhan akan perubahan.

33 Scot Davidson, Hak Asasi Manusia, Sejarah Teori, dan Praktek-praktek dalam Pergaulan Internasional, terjemahan A.Hadayana Pudjaatmaka (Jakarta: Pustaka Utama Grafiti, 1994), hlm. 40.

34 Nilai persamaan ini banyak dianut negara-negara di Asia yang diorientasikan kepada keluarga dan kolektivitas, mengutamakan kewajiban dan pertanggungjawaban daripada hak (Chris Brown, "Teori Politik dan Hubungan Internasional" dalam Gerald F.Gaus dan Chandran Kukathas, Op.cit, hlm. 673).

35 Jerome Frank, Hukum \& Pemikiran Modern, terjemahan Rahmani Astuti (Bandung: Nuansa, 2013), hlm. 389. Pound memandang hukum sebagai sarana untuk menjamin kepentingan sosial. Secara khusus, dia menganggap tuntutan akan stabilitas, kepastian dan keseragaman pada intinya sebagai akibat dari kepentingan sosial pada jaminan keamanan umum, atau sebagai yang sering diungkapkannya, kebutuhan sosial tertinggi akan jaminan keamanan umum, sebagaimana kepentingan akan keamanan dan ketertiban yang mengatur hukum sejak awal, telah mendorong manusia untuk mencari suatu landasan baku dari aturan tertentu bagi tindakan manusia yang harus dapat menjamin sebuah tatanan sosial yang tegas dan stabil.

36 William H. Shaw, "Teori Marx mengenai Sejarah dan Masyarakat" dalam Adam Kupper dan Jessica Kuper, Ensiklopedi Ilmu-ilmu Sosial, Edisi kedua, terjemahan Haris Munandar, (Jakarta: Raja Grafindo Persada, 2000), hlm. 620. Lihat juga Mohd. Koesnoe, Op.Cit., hlm. 126 yang menulis: "Bila diteliti lebih mendalam perincian ajaran Roscou Pound tersebut, menunjukkan kuatnya pengaruh ajaran Marx di situ". 
Politik Orde Baru telah membawa dampak yang meluluhlantakkan jalan menuju demokrasi. Untuk pertamakalinya secara legal dan sistematik dikurangi hak-hak dasar, terutama hak untuk ikut berpatisipasi dalam arena politik. Ditambah lagi Orde Baru telah juga membatasi hak-hak dasar banyak kelompok atau golongan masyarakat seperti buruh, mahasiswa, pemuda, wanita dan lain lain dengan cara membatasi ruang lingkup mereka untuk dapat berserikat secara mandiri. Lebih buruk lagi politik depolitisasi telah secara kasar itu menyebabkan terjadinya pembonsaian masyarakat sipil Indonesia. ${ }^{37}$ Dalam hal ini, negara atau pemerintah mempunyai posisi yang dominan terhadap individu. Aliran pemikiran ini lebih mengusung nilai persamaan ketimbang nilai kebebasan dalam membentuk dan menjalankan norma hukum.

Berbeda halnya, apabila negara dalam membuat dan melaksanakan hukum sebagai guardian of rights. Negara tidak sebagai pemberi hak, melainkan negara menguatkan kemauan dan keinginan hak moral untuk diaktualisasikan dalam kehidupan bernegara dan bermasyarakat. Undang-undang yang dibentuk ditujukan untuk mengukuhkan hak moral. Pada posisi ini, negara tunduk di bawah kemauan dan keinginan hak moral dengan mengedepankan hak kebebasan dan persaudaraan dalam membentuk norma hukum yang mengatur HAM, artinya dalam hal ini posisi negara menganut faham bahwa HAM sebagai hak negatif. Paham hukum yang akan dibuat didasarkan pada faham liberalisme individualis yang lebih mengedepankan hak dari pada kewajiban.

Secara historis, hal ini terlihat dari kemauan politik di Indonesia dengan diterapkannya secara eksplisit tentang HAM dalam reformasi konstitusi yang diikuti pula dengan ketentuan organiknya sebagai reaksi dari suasana perpolitikan pada era tahun 1990-an, dengan munculnya kritik-kritik yang mempertanyakan legitimasi government social control bersaranakan hukum perundangundangan yang difungsikan sebagai tool of social enginering. Dalam situasi seperti itulah gerakan-gerakan dari bawah untuk menuntut hak asasi mulai marak, ${ }^{38}$ yang pada puncaknya melahirkan kegiatan reformasi segala bidang di Indonesia pada tahun 1998.

Pergerakan menuntut hak asasi di Indonesia telah menghasilkan amandemen UUD 1945 salah satunya Pasal 1 ayat (2) Amandemen UUD 1945 yang esensinya hukum untuk manusia bukan manusia untuk hukum yang kemudian ditindaklanjuti lebih rinci dengan dituangkannya secara eksplisit HAM pada Bab XA.

Apa yang diuraikan pada sub bab ini, akibat dilapiskannya nilai kebebasan dengan 
nilai persamaan dan nilai perdamaian sebagai rechtsidee dalam Pembukaan UUD 1945, dalam tataran operasionalnya dipengaruhi oleh keinginan politik negara Indonesia sesuai kenyataan konkrit atas tuntutan dan kebutuhan zaman yang dihadapi bangsa Indonesia pada masanya. Hal ini memberi bukti, bahwa terdapat korelasi yang erat antara politik dan hukum demikian pula sebaliknya.

\section{Hak Sipil sebagai HAM di Indonesia}

Secara internasional, hak sipil sebagai HAM termuat di dalam ICCPR sebagai perjanjian multilateral yang diadopsi oleh Majelis Umum Perserikatan Bangsa Bangsa pada tanggal 16 Desember 1966 yang dinyatakan mulai berlaku pada 23 Maret 1976 yang pada intinya mengemukakan tentang hak atas integritas pisik, kebebasan dan keamanan pribadi, keadilan prosedural dan hak-hak terdakwa, kebebasan individu, dan hak-hak politik. ICCPR ini harus menjadi pedoman dan rujukan dalam membuat undang-undang hak sipil dan politik pada setiap negara peserta termasuk Indonesia yang telah meratifikasinya.

Secara teoritis, dalam literatur internasional menjadi kesepakatan, hak sipil dan politik adalah hak yang bersifat negatif. Setiap negara yang meratifikasi ICCPR tersebut harus membuat undang-undang yang isinya menjabarkan lebih operasional ketentuan ICCPR tersebut. Isi norma hukum yang dibentuk haruslah menempatkan posisi negara sebagai pengusung dan yang dibebani kewajiban guna mendukung, menghormati, dan menegakan hak-hak tersebut serta memberi ruang yang luas bagi setiap orang untuk menikmati hak sipil dan politik tersebut.

Kemauan politik bangsa Indonesia untuk melindungi dan menghormati hak sipil sebagai HAM di Indonesia dapat dilihat dari diratifikasinya ICCPR melalui UUPKIHSHP yang disahkan dan diundangkan pada tanggal 28 Oktober 2005. Hal ini membawa konsekuensi negara Indonesia berkewajiban menjunjung hak sipil dan politik sebagai hak moral (hak alamiah) diimplementasikan menjadi hak hukum. Pertimbangan Indonesia meratifikasi ICCPR dalam UUPKIHSHP adalah

1. HAM merupakan hak dasar yang secara kodrati melekat pada diri manusia, bersifat universal dan langgeng, dan oleh karena itu, harus dilindungi, dihormati, dipertahankan, dan tidak boleh diabaikan, dikurangi, atau dirampas oleh siapa pun;

2. Bangsa Indonesia sebagai bagian dari masyarakat internasional, menghormati, menghargai, dan menjunjung tinggi prinsip dan tujuan Piagam Perserikatan BangsaBangsa serta UDHR;

3. ICCPR pada dasarnya tidak bertentangan dengan Pancasila dan Undang-Undang Dasar Negara Republik Indonesia Tahun 1945, sesuai dengan sifat negara Republik Indonesia sebagai negara hukum yang menjunjung tinggi harkat dan martabat manusia yang menjamin persamaan kedudukan semua warga negara di dalam hu-kum, dan keinginan bangsa Indonesia untuk secara terus-menerus memajukan dan melindungi HAM dalam kehidupan berbangsa dan bernegara;

Dari pertimbangan tersebut dapat diketahui komitmen Pemerintah Indonesia untuk melindungi, menghormati, mempertahankan, dan tidak mengabaikan, tidak mengurangi atau merampas hak-hak tersebut oleh siapapun. Pada sisi lain, negara secara sukarela dan kesadaran sendiri telah menundukkan dirinya untuk tunduk dan patuh pada prinsip-prinsip 
hak sipil dan politik yang termuat di dalam ICCPR tersebut.

Dalam ICCPR terdapat dua hak, yaitu hak sipil dan hak politik sebagai hak moral. Esensi hak sipil dalam ICCPR ialah hak kebebasan fundamental yang diperoleh sebagai hakikat dari keberadaan seorang manusia, sedangkan hak politik esensinya adalah hak dasar dan bersifat mutlak yang melekat di dalam setiap warga negara yang harus dijunjung tinggi dan dihormati oleh Negara dalam keadaan apapun.

Apabila dicermati, isi ICCPR pada dasarnya adalah merupakan pedoman atau acuan bagi negara untuk melindungi, menghormati dan menjaga hak sipil dan politik, artinya, kaedah hukumyang termuat di dalam ICCPR menentukan kewajiban bagi negara untuk membuat undangundang yang mengatur tentang hak sipil dan hak politik dalam kedaulatan negara yang bersangkutan sebagaimana terlihat pada Bagian II, Pasal 2 ayat (1), ayat (2), dan ayat (3) ICCPR.

Pasal 2 ayat (1) ICCPR esensi adalah menetapkan hak sipil dan politik sebagai hak dasar manusia yang kodrati (hak moral) yang berlaku secara universal yang tidak tergantung pada hak-hak kenegaraan. Pasal 2 ayat (2) ICCPR esensinya adalah kewajiban setiap negara peserta untuk menentukan kebijakan hukum dan politik untuk mengatur hak sipil dan politik dalam suatu undang-undang atau menjadi kewajiban po-litik setiap negara peserta; sedangkan esensi Pasal 2 ayat (3) ICCPR adalah upaya negara untuk memulihkan pelanggaran terhadap hak sipil dan politik, pemulihan dilakukan melalui lembaga peradilan atau instansi resmi, dan jaminan atas pelaksanaan hak-hak tersebut.

Konsekuensi diratifikasinya ICCPR oleh negara Indonesia melalui UUPKIHSHP yang disahkan dan diundangkan pada tanggal 28 Oktober 2005, maka negara Indonesia mempunyai beban dalam bentuk kewajiban untuk melaksanakan isi ICCPR tersebut secara murni dan konsekuen. Dengan demikian, negara harus menderivasikan ketentuan ICCPR menjadi norma hukum yang dituangkan ke dalam peraturan perundang-undang untuk mengatur hak sipil di Indonesia secara lebih rinci dalam tataran opera-sional atau penegakannya secara nyata di Indonesia.

Apabila dicermati ketentuan perundangundangan yang ada di Indonesia. Pengaturan hak sipil sesungguhnya jauh lebih dahulu ada sebelum diratifikasinya ICCPR sebagaimana dapat dilihat dari Stb 1847-23 tanggal 30 April 1847 tentang BW (KUH Perdata) produk pemerintah Hindia Belanda; Staatblad ini, secara yuridis formal masih tetap berlaku berdasarkan Pasal I Aturan Peralihan Amandemen UUD 1945 "bahwa segala peraturan perundang-undangan yang ada masih tetap berlaku selama belum diadakan yang baru menurut UUD ini." 39

Hak sipil dalam Pasal 2 ayat (1) ICCPR secara normatif kelihatannya sesuai dengan Pasal 1, Pasal 2, dan Pasal 3 KUH Perdata. Ketiga ketentuan ini merupakan ketentuan esensial tentang integritas fisik dan kebebasan individu yang senafas dengan ketentuan Pasal 2 ayat (1) ICCPR. Argumentasinya dapat dilihat dari ketentuan Pasal 1 KUHPerdata yang 
mengatakan "menikmati hak-hak kewargaan tidak tergan-tung pada hak-hak kenegaraan." Apabila dicermati, frase "hak-hak kewargaan" dalam pasal tersebut memberi pengertian, bahwa hak kewargaan bersifat jamak atau merupakan seperangkat hak, dan hak tersebut merupakan hak sipil; Frase berikutnya "tidak tergantung pada hak-hak kenegaraan," artinya hak sipil tersebut diperoleh seseorang secara kodratiah karena martabatnya sebagai manusia. Pada sisi lain, pasal ini juga memberi arti bahwa setiap orang adalah subjek hukum. Hal ini juga senafas dengan ketentuan Pasal 16 ICCPR yang menentukan setiap orang berhak untuk diakui sebagai pribadi di hadapan hukum di mana pun ia berada. Oleh karenanya, tidak dapat disangkal, bahwa hak kewargaan atau hak sipil adalah hak fundamental bagi setiap manusia yang berlaku secara universal yang dalam litelatur internasional hak fundamen kodrati dinyatakan sebagai hak asasi setiap manusia. ${ }^{40}$

Sifat fundamental dan hak moral dari hak sipil (keperdataan) sebagai HAM pada Pasal 1 KUHPerdata terasa semakin menguat bila dikaitkan dengan Pasal 2 KUHPerdata yang mengatakan: "Anak yang masih dalam kandungan dianggap telah lahir, setiap kali kepentingannya menghendakinya; ${ }^{41}$ dan Pasal 3 KUH Perdata yang mengatakan: "Tiada satu hukuman pun yang mengakibatkan kematian keperdataan atau hilangnya segala hak-hak kewargaan." Ketiga pasal tersebut merupakan dasar utama tempat awal untuk diderivasikan hak-hak sipil lainnya, termasuk di dalamnya kebebasan untuk membuat kontrak atau perjanjian sebagaimana diatur dalam Buku III KUH Perdata.

Pengaturan hak sipil dalam ketentuan undang-undang sebagaimana termuat dalam Pasal 1, Pasal 2, dan Pasal 3 KUHPerdata memberi arti, bahwa hak sipil merupakan hak kodrati atau hak moral yang diimplemantasikan melalui hukum. Konsekuensinya, bahwa hak tersebut harus ditegakkan, dihormati, dan dilindungi oleh setiap orang mau pun negara. Dalam konteks kenegaraan, negara diberi beban kewajiban untuk melindungi, pemajuan, penegakan, dan pemenuhan HAM.

Nilai yang termuat pada Pasal 1, Pasal 2 dan Pasal 3 KUH Perdata adalah nilai kebebasan. Nilai ini bersesuaian dengan salah satu dari tiga nilai yang termuat di dalam Pembukaan UUD 1945 yaitu nilai kebebasan, keadilan dan perdamaian sebagai pengejawantahan dari Sila Ketuhanan Yang Maha Esa bahwa hak sipil sebagai hak moral, dan Sila Kemanusiaan yang adil dan beradab memuat nilai kebebasan.

Dari uraian di atas, dapat diketahui bahwa sesungguhnya tindakan negara meratifikasi ICCPR secara praktis penguatan hak sipil yang sudah ada sebagaimana termuat dalam $\mathrm{KUH}$ Perdata. Masalah yang mendasar adalah berkaitan dengan penegakan hak sipil adalah dalam tataran praktisnya, yakni komitmen

40 Bandingkan dengan ketentuan Pasal 1 angka 1 UU Nomor 39 Tahun 1999 tentang Hak Asasi Manusia yang mengatakan: "Hak Asasi Manusia adalah seperangkat hak yang melekat pada hakikat keberadaan manusia sebagai makhluk Tuhan Yang Maha Esa dan merupakan anugerah-Nya yang wajib dihormati, dijunjung tinggi dan dilindungi oleh negara, hukum, pemerintah, dan setiap orang demi kehormatan serta perlindungan harkat dan martabat manusia".

41 Pasal ini memberi pengertian, hak untuk hidup dan kehidupan merupakan hak yang esensial bagi manusia. Lihat juga Pasal 9 ayat (1) UU Nomor 39 Tahun 1999 tentang Hak Asasi Manusia yang mengatakan "Setiap orang berhak untuk hidup, mempertahankan hidup dana meningkatkaan taraf kehidupannya". 
dan konsistensi penegakan HAM oleh individu maupun oleh negara melalui pengadilan dan kebijakan pemerintah.

\section{Hubungan kontraktual sebagai HAM dan penegakannya di Indonesia}

Pasal 11 ICCPR secara tegas menyatakan tidak seorang pun dapat dipenjara sematamata atas dasar ketidakmampuannya untuk memenuhi suatu kewajiban yang muncul dari perjanjian. Pasal ini mengandung arti, bahwa kebebasan seseorang membuat perjanjian adalah hak dasar bagian dari hak sipil yang demikian melekat pada diri setiap individu dan negara tidak dibenarkan mengurangi atau tidak menghormatinya bahkan mencampurinya, artinya negara tidak dibenarkan untuk intervensi terhadap hubungan antar individu dalam menikmati hak sipilnya.

Di atas telah dikemukakan, KUHPerdata pada dasarnya adalah pengaturan hukum tentang hak sipil yang esensinya senafas ICCPR. Buku III KUHPerdata khususnya dalam Pasal 1338 KUHPerdata mengatur tentang kebebasan berkontrak dan hal ini merupakan asas hukum sebagai implementasi kebebasan sipil. Kebebasan berkontrak merupakan pikiran dasar yang memberi roh keberlakukan dan kekuatan hukum materil pada norma hukum kontrak di samping dan kaitannya dengan kekuatan hukum formal. ${ }^{42}$ Kebebasan berkontrak sebagai asas hukum bagi kaedah hukum perjanjian yang hingga kini tetap menjadi asas penting dalam sistem hukum kontrak baik dalam sistem civil law, common law, maupun sistem lainnya, termasuk sistem hukum Islam. ${ }^{43}$

Kebebasan berkontrak didalamnya terkandung lima prinsip hukum, yaitu (a) kebebasan menentukan isi kontrak (b) kebebasan menentukan bentuk kontrak (c) mengingat para pihak (d) aturan memaksa (mandatory rules) sebagai perkecualian, dan (e) Sifat internasional dan tujuan-tujuan prinsip-prinsip UNIDROIT yang harus d-perhatikan dalam penafsiran kontrak. ${ }^{44}$ Esensi sifat kebebasan dalam melakukan kontrak berisikan hak dan kebebasan individu yang demikian melekat pada diri setiap manusia dan apa yang mereka perbuat dalam kontrak tersebut mengikat bagi kedua belah pihak sebagaimana layaknya suatu undang-undang. Dari situ dapat diketahui, bahwa demikian eratnya kebebasan berkontrak terhadap diri manusia sebagai manusia. Hal ini senafas dengan Pasal 11 ICCPR. Asas kebebasan berkontrak ini merupakan derivasi dari ketentuan yang termuat dalam Pasal 1, Pasal 2, dan Pasal 3 KUH Perdata.

ICCPR menegaskan, penegakan dan penghormatan terhadap hak sipil tidak saja harus dilakukan oleh negara tetapi juga oleh setiap orang. Cara bagaimana individu dan negara menghormati dan penegakan hak sipil khususnya hubungan kontraktual dapat dilihat pada Pasal 1320 KUH Perdata tentang syarat sahnya perjanjian yakni (a) adanya kesepakatan (b) cakap membuat perjanjian (c) hal tertentu 
(d) sebab yang halal. Syarat a dan b merupakan syarat subjektif dan syarat $\mathrm{c}$ dan $\mathrm{d}$ merupakan syarat objektif.

Syarat subjektif dalam perjanjian berhubungan dengan keadilan prosedural membuat perjanjian. Syarat ini berkaitan dengan penghormatan atas harkat dan martabat sesama manusia yang akan membuat kontrak agar tidak terjadi pelanggaran martabat manusia dengan mengeksploitasi manusia atas manusia lainnya demi ke-pentingan sepihak. Hal ini dapat dilihat dari ketentuan membuat kontrak tidak boleh didasarkan penipuan, paksaan, kekeliruan atau penyalahgunaan keadaan. Bila hal ini terjadi pada saat proses pembuatan perjanjian, maka perbuatan tersebut telah me-langgar hak sipil seseorang atau telah menyerang atau merampas harkat dan martabat manusia secara sewenang-wenang.

Syarat objektif dalam perjanjian berkaitan dengan keadilan substantif, artinya pihakpihak yang membuat perjanjian harus tunduk pada nilai keadilan substantif yang termuat di dalam ketentuan undang-undang, ketertiban umum atau kesusilaan. Nilai tersebut sebagai parameter utama yang harus dipegang teguh membuat dan melaksanakan perjanjian agar tidak terjadi pelanggaran hak seseorang atas sesuatu yang telah diakui secara umum atau rasa keadilan umum dalam kehidupan bersama. Dalam konteks ini, ada beberapa kritik yang dapat dikemukakan terhadap ketentuan undangundang yang mengkriminalisasi hubungan sipil dan kekeliruan penegakan hukum dalam penyelesaian hubungan sipil melalui aktivitas di pengadilan sebagai konsekuensi negara Indonesia sebagai negara hukum. Oleh karena itu, pengadilan adalah pilar utama negara hukum. Untuk itu, amat tepat dan objektif untuk melihat kebijakan negara terhadap hubungan kontraktual sebagai HAM dari apa yang telah diputuskan melalui pengadilan.

Putusan pengadilan yang dapat diajukan dalam tulisan ini tentang penyelesaian kasus hubungan kontraktual pengadaan barang dan jasa yang dilakukan oleh pihak swasta dengan pemerintah (negara), di mana pengadilan memberikan hukuman pidana kepada pihak swasta yang tidak memenuhi kontrak kerja sesuai yang ditentukan dalam spesifikasi yang telah disepakati. ${ }^{45}$ Dari kasus ini, terlihat bahwa negara, melalui pengadilan, telah melakukan pelanggaran terhadap hak sipil sebagai HAM sebagai-mana yang ditentukan oleh Pasal 11 ICCPR dan Pasal 2 ICCPR tentang kewajiban negara untuk menghormati, melindungi dan menegakkan hak sipil sebagai HAM. Perbuatan negara yang demikian ini jelas-jelas bertentangan dengan kemauan politik dan janjinya sendiri sebagaimana termuat pada pertimbangan diratifikasinya ICCPR, pada sisi lain hal ini juga membuktikan telah melanggar ketentuan Pasal 2 ayat (1), ayat (2) dan ayat (3) ICCPR.

Penerapan pidana melalui pengadilan terhadap pelanggaran atas hubungan

45 Putusan Pengadilan Tinggi Medan Nomor 106/Pid.B/2011/PN.Mdn tanggal 22 Februari 2011 dalam pertimbangan hukumnya mengatakan "Pengadilan berpendapat bahwa memang antara terdakwa dengan Dinas Perikanan dan Kelautan Kota Medan berawal adanya hubungan perjanjian antara individu dengan negara atau pemerintah, namun yang didakwakan oleh Penuntut Umum bahwa akibat adanya hubungan kontrak pengadaan barang berupa 20 boat beserta alat peralatannya tidak sesuai dengan spesifikasi yang termuat dalam kontrak yang menimbulkan kerugian negara". 
kontraktual sungguh sungguh telah mencederai keadilan substansial yaitu tentang substansi hukum juga mencederai keadilan prosedural yaitu penyelesaian hubungan sipil melalui domain pidana. Untuk ini, menarik apa yang dikemukakan Gustaf Radburch pada ajaran prioritas baku tentang tujuan hukuman yaitu keadilan harus diprioritaskan, yaitu manakalah Hakim harus memilih antara keadilan dan kemanfaatan maka pilihan hakim haruslah kepada keadilan, demikian juga ketika hakim diperhadapkan dengan kemanfaatan dan kepastian hukum maka haruslah dipilih kemanfaatan hukum, keadilan tersebut harus dirasakan oleh seluruh anggota masyarakat, bukan hanya untuk memenuhi rasa keadilan bagi sebagian kecil anggota masyarakat atau kelompok atau sejumlah orang tertentu.

Kasus lain dapat diajukan pada tulisan ini adalah Putusan Pengadilan Negeri Stabat atas hubungan kontraktual antara sesama individu yang diberi sanksi pidana oleh pengadilan terhadap perbuatan penitipan uang sebesar Rp 1.296.800.000; yang dikualifikasi sebagai penipuan (Pasal 378 KUHPidana). ${ }^{46}$ Atas dasar hukuman pidana tersebut, pihak terpidana kemudian digugat secara perdata di Pengadilan Negeri Binjai oleh saksi korban (pihak yang menitipkan uang) dengan dalil gugatan, bahwa Tergugat (Terpidana) telah melakukan wanprestasi. Pengadilan Negeri Binjai mengabulkan gugatan Penggugat dan menghukum Tergugat (telah dipidana karena menerima titipan uang) untuk mengembalikan uang sebesar $\mathrm{Rp}$ 1.296.800.000; berikut bunga $6 \%$ per-tahun yang kemudian dikuatkan oleh
Putusan Mahkamah Agung RI No. 3158K/PDT/ 2011 tanggal 16 Juli 2012.

Dari kasus yang disebutkan terakhir dapat diketahui, terdapat dua hal penting untuk dikemukakan berkaitan penegakan dan penghormata hak sipil sebagai HAM. Pertama, hubungan kontraktual diberikan sanksi pidana oleh negara. Kedua, negara telah memberi sanksi ganda terhadap hubungan kontraktual yang dilakukan oleh sesama individu pada satu sisi dihukum pidana dan pada sisi lain diberi sanksi mengembalikan uang berikut bunga. Perbuatan negara yang demikian ini sungguh nyata sekali telah menindas rakyatnya sendiri. Hal ini bertentangan Pasal 1 ayat (2) UUD 1945 yaitu kedaulatan di tangan rakyat yang esensinya hukum untuk manusia bukan manusia untuk hukum.

Dua kasus di atas membuktikan negara telah melakukan pelanggaran HAM dan tidak konsisten menjalankan ICCPR dengan melanggar pernyataannya sendiri sebagaimana yang dituangkannya dalam pertimbangan untuk meratifikasi ICCPR melalui UUPKIHSHP dan juga jelas-jelas bertentangan dengan Pasal 1 ayat (1), ayat (2) dan ayat (3) ICCPR. Pada sisi lain ketentuan pidana yang memuat hak subjektif yakni penggelapan barang, penipuan, merugikan orang yang berpiutang, penghinaan yang termuat di dalam KUHPidana bertentangan dengan perlindungan hak sipil sebagaimana yang ditentukan di dalam ICCPR. Padahal dalam KUH Perdata sendiri telah diatur perlindungan pihak yang dirugikan hak subjektifnya diselesaikan melalui domain perdata sebagaimana terlihat di dalam ketentuan Pasal 1365 KUH Perdata 
tentang perbuatan melawan hukum, dan pembatalan perjanjian karena paksaan, tipuan dan kekeliruan, juga tuntutan ganti rugi akibat pencemaran nama baik.

Pemidanaan terhadap hubungan kontraktual sebagaimana kasus di atas memberi fakta negara telah meluluhlantakkan peradaban bangsa dan bangunan negara hukum. Padahal dalam sejarah perjalanan umat manusia menunjukkan hubungan berbanding lurus antara hukum dan peradilan dengan peradaban suatu bangsa. Tidak ada bangsa yang dikategorikan beradab tanpa mempunyai hukum yang baik dan peradilan yang baik. Oleh karenanya, pengadilan mempunyai arti penting bagi suatu bangsa, karena peradilan mempunyai posisi yang strategis dan sangat penting bagi bangunan suatu negara hukum.

Dari kasus yang telah dikaji dalam tulisan ini, terbukti bahwa negara telah melakukan pelanggaran terhadap hak sipil dari warganya yakni tentang integritas fisik dan kebebasan individu. Namun, terhadap pelanggaran ini negara tidak mempertanggung-jawabkan perbuatannya. Ini membuktikan negara berada di atas manusia dan terlihat hukum digunakan oleh negara secara sewenangwenang dengan menggunakan hukum yang substansinya bertentangan dengan HAM. Alihalih negara bukannya melindungi hak sipil malah menghancurkannya.

Fakta di atas membuktikan kebijakan politik Indonesia menganut faham klasik tentang negara. Negara difahami sebagai lembaga politik tertinggi, terutama sebagai lembaga penyedia keamanan dan kestabilan. Pada hal, dalam literatur masa kini, pandangan nilai politik diyakini mengandung sifat keadilan distributif, melindungi oto-nomi individu, memupuk rasa kebersamaan, bentuk-bentuk demokrasi liberal, dan memelihara kelestarian lingkungan. Semua ini mencerminkan suatu pandangan terhadap negara sebagai yang memungkinkan manusia dan masyarakat tumbuh berkembang dengan baik, meski juga membolehkan negara dihadari dengan macam-macam upaya untuk menegaskan lagi individu rasional kontemplatif sebagai sumber nous politik dan tak jarang menegaskan kembali komunitas budaya sebagai tempat identitas-merangkap-otonomi individual. ${ }^{47}$ Fakta ini juga membuktikan negara melang-gar Pasal 1 ayat (2) UUD 1945 tentang kedaulatan di tangan rakyat dan dilaksanakan menurut UUD yang esensinya, hukum untuk manusia bukan manusia untuk hukum.

\section{E. Penutup}

\section{Kesimpulan}

Dari analisis yang dilakukan terhadap data yang dipergunakan dalam tulisan ini disimpulkan bahwa hak sipil di Indonesia telah diatur dalam KUHPerdata, jauh sebelum diratifikasinya ICCPR, yang isinya sesuai dan senafas dengan ketentuan yang ter-muat di dalam ICCPR. Negara, melalui pengadilan, telah memberikan hukuman pidana terhadap hubungan kontraktual dan memberikan hukuman ganda, yakni menghukum secara perdata dan pidana membuktikan negara tidak konsisten dalam menjalankan ICCPR yang telah diratifikasi dalam upaya melindungi hak sipil di Indonesia. Dalam rangka melindungi HAM,

47 Michael Freeden, "Idiologi, Teori Politik, dan Filsafat Politik" dalam Gerald F.Gaus dan Chandran Kukathas, Handbook Teori Politik, terjemahan Derta Sri Widowatie (Bandung, Nusa Media, 2012), hlm. 6-7. 
posisi negara sebagai legulator of rights dalam penegakan hak sipil saat menyelesaian sengketa hubungan kontraktual.

\section{Rekomendasi}

Dari hasil penelitian ini disarankan untuk penegakkan hal sipil sebagai HAM di Indonesia negara harus mereposisi peran dan fungsi negara dalam membentuk norma hukum tentang hak sipil dalam ketentuan undang-undang dengan lebih menekankan negara mempunyai beban kewajiban untuk melindungi, menghormati dan menegak-kan hak sipil di Indonesia serta pertanggungjawaban negara atas pelanggaran hak sipil yang dilakukannya. Pada sisi lain, perlu dilakukan perubahan atau mencabut ketentuan pidana yang berkaitan dengan hak subjektif (hak sipil) yang termuat di dalam KUH Pidana yang isinya tidak senafas dengan esensi ICCPR. Negara harus memposisikan dirinya sebagai penyeimbang dalam menyelesaikan konflik hak sipil dalam hubungan kontraktual sesuai dengan semangat yang dikehendaki oleh ICCPR.

\section{DAFTAR PUSTAKA}

\section{Buku}

Algra, N.Eetal., Mula Hukum BeberapaBabmengenai hukum dan ilmu untuk pen-didikan hukum dalam Pengantar IImu Hukum, terjemahan J.C.T. Simorangkir, (Jakarta: Binacipata 1983).

Badrulzaman, Mariam, Kompilasi Hukum Perikatan (Bandung: Citra Aditya Bakti, 2001).

Cahyono, Edi Cahyono, Demokratitasi di Era Globalisasi Konfferensi INFID ke-11, BonnJerman, 4-6 Mei 1998, (Jakarta: INFID, 1999).

Cipta Adi Pustaka, PT, Ensiklopedi Nasional Indonesia Buku 15, (Jakarta: PT.Cipta Adi Pustaka, 1991).

Davidson, Scot, Hak Asasi Manusia, Sejarah Teori, dan Praktek-praktek dalam Per-gaulan Internasional, terjemahan A.Hadayana Pudjaatmaka, (Jakarta: Pustaka Utama Grafiti, 1994).
Feith, Herbert dan Lance Castles, Pemikiran Politik Indonesia 1945-1965, terjemahan, Yubhar (Jakarta: LP3ES, 1995).

Frank, Jerome, Hukum \& Pemikiran Modern, terjemahan Rahmani Astuti (Bandung: Nuansa, 2013).

Fukuyama, Francis, Memperkuat Negara Tata Pemerintahan dan Tata Dunia Abad 21, terjemahan, A. Zain Rofiqi (Jakarta: Gramedia Pustaka Utama, 2005).

Gaus, Gerald F dan Chandran Kukathas, Handbook Teori Politik, terjemahan Derta Sri Widowatie (Bandung: Nusa Media, 2012).

Kasim, Ifdal, Johanes dan Masenus Arus, Hak Ekonomi, Sosial, Budaya, Esai-esai Pilihan, (Jakarta: Elsam, 2001).

Koesnoe, Mohd, "Mengamati Konsep Hukum di Dalam Masyarakat Kita", Varia Peradilan, No. 105 (1994).

Koesnoe, Mohd, Catatan-catatan Terhadap Hukum Adat Dewasa ini (Surabaya: Arilangga University Press, 1979).

Kupper, Adam dan Jessica Kuper, Ensiklopedi IImuIImu Sosial, Edisi Kedua, (Jakarta: Raja-Grapindo Persada, 2000).

Nugroho, Heru, Negara, Pasar, dan Keadilan Sosial, (Yogyakarta: Pusaka Pelajar, 2001).

Pakan, Djon, Kembali ke Jati diri Bangsa Indonesia, (Jakarta: Millennium Publisher, 2002).

Rousseau, Jean Jacques, Kontrak Sosial, terjemahan, Sumardjo (Jakarta: Erlangga, 1986).

Shidarta, Mochtar Kusumaatmadja dan Teori Hukum Pembangunan Eksistensi dan Implikasi (Jakarta: Epistema Institute dan Huma, 2012).

Silalahi, S, Dasar-dasar Indonesia Merdeka versi Para Pendiri Negara ( Jakarta: Gramedia, 2001).

Soehino, Ilmu Negara, (Yogjakarta: Liberty, 1980).

Sukarno, Di bawah Bendera Revolusi, (Jakarta: Panitya Penerbit Di bawah Bendera Revolusi, 1964).

Von Schmid, J.J, Ali-ahli Pikir Besar Tentang Negara Dan Hukum, terjemahan, (Jakarta: Pembangunan, 1965).

Zoelfirman, Kebebasan Berkontrak vesus Hak Asasi Manusia Analisis yuridis Hak Ekonomi, Sosial dan Budaya (Medan: UISU Press, 2003).

\section{Internet}

http://icjr.or.id/mengenal-kovenan-internasionalhak-sipil-dan-politik (diakses 2 Mei 2012). 
http://en.wikipedia.org/wiki/Human_rights (diakses 13 April 2013).

www.suaramerdeka.com/v2/index-php/read/news. smg/2012/05/19/118844/Prof-Sri-Redjekisampaikan Orasi-ilmiah-di-Undip (diakses 4 Mai 2013)

www.bphn.go.id/index.php?action=public. id=2008042815080192 (diakses 27 April 2013),

\section{Peraturan}

Undang Undang Dasar Negara Republik Indonesia Tahun 1945

Undang-Undang Nomor 12 Tahun 2005 tentang Pengesahan Kopenan Internasional Hak Sipil dan Hak Politik.

Undang-Undang Nomor 39 Tahun 1999 tentang Hak Asasi Manusia.
Undang-Undang Nomor 5 Tahun 1960 tentang Ketentuan Pokok Agaria.

Kitab Undang Undang Hukum Perdata staadblad 1847-23 tanggal 30 April 1847.

Undang-undang Nomor 1 Tahun 1974 tentang Perkawinan.

\section{Putusan Pengadilan}

Putusan Mahkamah Agung Rı Nomor No. 3158K/ PDT/ 2011 tanggal 16 Juli 2012.

Putusan Pengadilan Tinggi Medan Nomor 106/ Pid.B/2011/PN.Mdn tanggal 22 Februari 2011.

Putusan Pengadilan Negeri Stabat No. 06/ Pid.B/2010/PN.Stb tanggal 25 Maret 2010 